\title{
Kamu Diplomasisi Perspektifinden Ulus Markalaması
}

\author{
Ergün Köksoy'
}

\begin{abstract}
Öz
Kamu diplomasisi ve ulus markalaması kavramları ülkelerin değerlerinin, görüşlerinin, ideallerinin diğer ülke halklarına anlatılması, bu halklarla iyi ilişkiler kurulması ve ulus hakkındaki genel algıların yönetilmesi ile ilişkili bulunmuştur. Ülkeler ve hükümetler, çeşitli iletişim, pazarlama ve markalama yöntemlerini kullanarak kendilerine has somut ve soyut değerleri ön plana çıkarmaya, bu değerler yoluyla diğer ülkelerden farkıılaşmaya çalışmaktadır. Bu farklılaşmada esas amaç uluslar arası toplum nezdinde saygınlık kazanmak, dış politikaların uygulanmasına ve ülke çıkarlarının elde edilmesine uygun ortamlar yaratmak iken bunun yolu yabancı ülke halklarıyla iyi ilişkiler kurmak ve onların zihninde farklı ve olumlu bir yer edinmekle mümkündür. Bu çalışmanın literatür bölümünde kamu diplomasisi ve ulus markalaması ilişkisine ve bu ilişkiye ilişkin akademik görüşlere, yorumlara yer verilecektir. İki alan arasındaki bağlantıların ele alınması sonucu ortaya çıkan yaklaşımlar Türkiye kamu diplomasisi ve Türkiye ulus markalaması anlayışı ve faaliyetleri özelinde değerlendirilecek, kurumsallaşmaya ve uygulamaya dönük öneriler sunulacaktır.
\end{abstract}

Anahtar Kelimeler: Kamu Diplomasisi, Türkiye Kamu Diplomasisi, Ulus Markalaması, Türkiye Ulus Markalaması, Türkiye Markası.

\section{Nation Branding From The Perspective Of Public Diplomacy}

\begin{abstract}
The concepts of public diplomacy and nation branding are associated with conveying the ideals, values, and thoughts to people of other countries, establishing good relations with them and managing public perception about the nations. The main objective of the two areas, of which countries are trying to shine the spotlight on their own tangible and intangible values using various methods of communication and branding and also trying to differentiate themselves from other countries with the obvious differences, seeking to manage these differences in a way that will contribute to the foreign policy and national goals, is to get a different and positive image in the minds of foreign people. Namely, the target is to create positive images and perceptions and manage them. Assessing the relationship between these two concepts will form the literature part of the essay. The concept of nation branding from the perspective of public diplomacy will be discussed from the standpoint of Turkey. However, the actors and activities of Turkish public diplomacy will be assessed in general terms. The results of the relationship between the two areas will be presented with reference to the opinions expressed in the literature.
\end{abstract}

Keywords: Public Diplomacy, Turkish Public Diplomacy, Nation Branding, Turkish Nation Branding, Turkish Brand.

1 Dr, 2013 yılında i..Ü. Sosyal Bilimler Enstitüsü Halkla İlişkiler ve Tanıtım Anabilim Dalından "Halkla İlişkiler Bağlamında Kamu Diplomasisi Yönetimi [Türkiye'nin Kamu Diplomasisindeki Yetkinlik İncelemesi] adlı tez çalışmasıyla doktora derecesi aldı. 


\section{Giriș}

letişim teknolojilerinde yaşanan gelişmeler son yüzyılda gerek ulusal gerekse uluslararası politik, ekonomik, sosyal ve kültürel alanlarda önemli değişikliklere yol açtı. Ulaşım ve iletişim ağlarının sağladığı küresel bağlantılar, uluslararası politik, ekonomik sosyal sistemler arasında artan bağımlııı, küresel düzlemde ortaya çıkan sorunlar karşısında ortak mücadele gerekliliği, uluslararası işbirliği ve ilişkileri daha da önemli kıldı. Bu hızlı dönüşümün yaşandığı günümüzde ülkeler, hükümetler ve siyasal aktörler uluslararası ilişkilerin ve politikanın ana aktörü olma niteliklerini büyük oranda kaybederek, bu rolü birçok ulusal ve uluslararası sivil aktörle paylaşmak zorunda kaldı. Sivil toplum kuruluşları, bağımsız kurumlar ve birlikler, şirketler, akademik ve kültürel örgütlenmeler, medya ve iletişim kurumları, vatandaşlar ülkelerin dış politikaları ve uluslararası ilişkilerinde göz önünde bulundurulması ve süreçlere dahil edilmesi gereken aktörler haline geldi. Diplomasi, iletişim teknolojileriyle beraber paradigma değiştirdi ve yeni aktörler, uluslararası ilişkilerde büyük rollere sahip oldu (Sancar, 2015).

Bu değişim ve etkileşim aynı zamanda uluslararası ilişkiler ve uluslar arası iletişim alanlarında yeni yöntemlerin ve kavramların ortaya çıkmasını sağladı. Ülkelerin dış ilişkilerini yürüttükleri, diplomattan - diplomata, ya da devletten - devlete olan diplomatik ilişki biçimi değişti. Klasik diplomasi sisteminin, ülkelerin dış ilişkilerini ve iletişimlerini yönetmekte başarısız kalmasıyla kamu diplomasisi, ülkelerin saygınlığı ve prestiji ile doğrudan ilişkili olan ulusal imaj ve algıların yönetilmesi gerekliliğiyle de ulus markalaması kavramları ortaya çıktı. Kamu diplomasisi ilk dönemlerde sadece hükümetlerin daha sonra ise hükümet dışı organizasyonların, sivil toplum kuruluşlarının, özel sektör kurumlarının ve vatandaşların diğer ülkelerdeki muhataplarıyla iyi ilişkiler kurma,onları bilgilendirme, kalplerini kazanma, ülke imajını geliştirme, yabancı kamularla iletişime geçme ve hükümetlerin dış iletişimi olarak tanımlanmıştır. Ulus markalaması ise uluslararası kamuoyunda ulus imajlarının yaratılması, kültür ve değerlerinin sunulması, algılarının yönetilmesi ve saygınlığının arttırılması ile ilişkili bulunmuştur.

Uluslararası ilişkiler ve uluslar arası iletişim alanlarında ortaya çıkan kamu diplomasisi ve ulus markalaması arasında benzerlikler ve ortaklıklar bulunduğu ileri sürülmüştür. Ülkeler ve toplumlar arasındaki siyasal, ekonomik, kültürel ve sosyal etkileşimlerle ortaya çıkan bu iki alanın ilişkisinin incelenmesi, değerlendirilmesi, ülkelerin dış ilişkilerini ve ulus imajlarını yönetmelerine katkı sağlayacak iletişim olanakları sunacaktır. İi kavram arasındaki ilişkinin ve ortaya çıkacak iletişim olanaklarının değerlendirilmesi ve akademik bir yoruma tabi tutulması bu çalışmanın ana amacıdır. Bu ilişkinin sonuçları, Türkiye kamu diplomasisi perspektifinden kısaca değerlendirilerek, Türkiye özelindeki kurumsallaşma ve uygulama çalışmalarına yönelik öneriler sunulacaktır.

\section{İletișim Yönetimi Olarak Kamu Diplomasisi}

Kamu diplomasisi kavramını ortaya çıkaran temel unsur, ülkelerin, hükümetlerin diğer ülke halklarıyla iletişim ve ilişki kurma intiyaçları olmuştur. Başlangıçta, bu ihtiyaç sadece hükümetlerin dış politika amaçlarına ulaşmak için yabancı halkları kendi hükümetleri üzerinde bir baskı aracı haline getirmeye yönelikti. Kamu diplomasisi alanının ana aktörü hükümetlerdi. Uygulanan iletişim yöntemi ise tek yanlı ve siyasal etki oluşturma amaçlıydı. Hükümetlerin kamu diplomasisi süreçleri üzerindeki hakimiyetini kaybetmesiyle kamu diplomasisi daha sivil bir nitelik kazandı. Bu değişim, kavrama ilişkin tanımlara ve tarihsel süreçlere de yansımıştır.

Kamu diplomasisinin modern bir alan olarak ortaya çıkışı II. Dünya Savaşı sonrası Soğuk Savaş dönemine rastlamaktadır. Bir terim olarak kullanımı ve uygulama örnekleri ise 19. yüzyılın 
ortalarına kadar gitmektedir. (Szondi, 2008: 2). Ülkelerin başka ülkelerde kurdukları dil okulları, radyo kanalları, klasik diplomatik ilişkileri destekleyen resmi ve sivil seyahatler, festivaller, fuarlar, kamu diplomasisinin ilk döneminde sıklıkla rastlanan ve karşılaşılan uygulamalar olmuştur. Kavrama ilişkin ilk akademik tanımlama Tufts Üniversitesi Fletcher Hukuk ve Diplomasi Okulu Dekanı Edmund Gullion (1965) tarafından yapılmıştır. Gullion, kamu diplomasisini, kamuoyu davranışlarının dış politika oluşumuna ve yürütmesine etkisi, geleneksel diplomasinin ötesinde uluslararası ilişkilerin farklı boyutlarını kapsaması olarak tanımlamıştır (Demir, 2012: 6).Bir başka görüşe göre ise kamu diplomasisi kavramı ilk kez 1963 yılında ABD'de Kennedy hükümeti döneminde $A B D$ Bilgilendirme Ajansı (USIA -United States Information Agency) Müdürü Edward Murrow tarafından kullanılmıştır. Murrow, kamu diplomasisini, hükümet ve hükümet dışı oluşumların görüşlerinin yabancı sivil toplum kuruluşları ve kamuoylarıyla paylaşılma süreci olarak tanımlamıştır (İnan, 2012: 64).Bu tanımlar kamu diplomasisini, geleneksel diplomasinin dışında kalan uluslararası ilişkiler alanlarıyla ilişkilendirmiş, diğer ülkelerin kamuoylarının görüşlerinin etkilenmesi,yabancı ülkelerdeki özel gruplar ve sivil topluluklarla etkileşimin sağlanması, dış politika konularının haberleştirilmesi, muhabirler ve diplomatlar arasındaki iletişim ve kültürel etkileşim çalışmaları ile doğrudan bağlantılandırmıştır. (Szondi, 2008: 2).

Kamu diplomasisinin ilk dönemi olarak kabul edilecek bu dönemde yapılan tanımlamalar Soğuk Savaşın da etkisiyle hükümet kaynaklı etki oluşturma ve ikna odaklıdır. Kamu diplomasisi sert gücün (politik, askeri, ekonomik) bir parçasıdır ve politikalara yöne veren anlayış tamamen siyasaldır. Kültür ve değerler kitle medyası aracılığıyla toplumlar üzerinde etki oluşturmak için kullanılmıştır.Kamu diplomasisi propaganda ile birlikte psikolojik savaş aracı olarak görülmüştür. 1960 'ı yıllarda, daha sonra bütün uygulamalarını kamu diplomasisi faaliyeti olarak adlandıracak ABD Bilgilendirme Ajansı, bilgilendirme ve propaganda kavramlarının olumsuz izlenimlerinden kurtulmak için 'kamu diplomasisi' kavramını kullanmıştır. (Cull, 2009: 20).

Kamu diplomasisinin kökenleri devletler ve diğer aktörler arasındaki çatışmalar ve gerilimler etrafında şekillenmiştir. Bunun en önemli göstergesi, kamu diplomasisi ve yöntemlerinin, ABD ve Batılı ülkeler tarafından Soğuk Savaş sürecinde yoğun olarak kullanılmasıdır. Bu süreçte kamu diplomasisi ve yöntemleri, Amerikan ve Batı politikalarının Demir Perde olarak nitelendirilen Doğu Avrupa ülkelerine yayılması amacıyla kullanıımıştır. Bu kamu diplomasisi anlayışı, Berlin Duvarı'nın yıkılmasına (Soğuk Savaşın bitişi) kadar sürmüştür (Szondi, 2008: 3).

Soğuk Savaşın sonlarına doğru uluslar arası alanda ekonomik, sosyal ve kültürel ilişkilerin tekrar canlanmasıyla, ABD ve Sovyetler Birliği (SSCB) arasındaki gerilim politikalarının yerini yumuşamaya bırakmasıyla kamu diplomasisi kavramına ilişkin tanımlar da değişmiş̧tir. Toplumlar arasındaki kültürel ve sosyal etkileşimlere yapılan vurgu artarken kamu diplomasisinin, propaganda, psikolojik savaş gibi sert güç unsurlarıyla arasındaki mesafe artmış ya da daha örtük hale gelmiştir. Soğuk Savaş dönemindeki sert güç kavramı, yeni uluslar arası sistemde yerini ülkelerin "yumuşak güçlerine" bırakmıştır. Ülkeler artık sahip oldukları yumuşak güç potansiyeli ile (bilim, sanat, kültür, spor, eğitim vb.) başka ülkeleri etkilemeye, onlar için cazip bir ülke konumuna gelmeye ve bu süreçte kendi politikalarını başka ülkelere kabul ettirmeye çalışmışlardır. Bu sürecin temelini iletişim, etkileşim, ikna ve işbirliği oluşturmuştur. (Özkan, 2014)

Örneğin, 1987 yılında Amerikan Hükümeti tarafından yapılan bir tanımda kamu diplomasisi, diğer ülkelerde kamuoyu oluşturmak ve etkilemek amacıyla hükümetin desteğinde gerçekleştirilen basılı yayınlar, filmler, kültürel değişimler, radyo ve televizyon faaliyetlerinin gerçekleştirilmesi olarak ifade edilmiştir (Inan, 2012: 64). Kamu diplomasisi, milli menfaatlerin tanımlanması, hükümetlerin iletişim politikalarının, dış politikasının yönlendirilmesi, klasik diplomasi harici 
kültürel diplomasisinin kapılarının aralanması, ülkelerin imajlarının şekillendirilmesi, algılama idaresi sanatı, fikirlerin tedavülü, doğru bilginin yayılması, milletlerarası zeminin idare edilmesi, münasebetlerin inşa edilmesi gibi unsurlarla ilişkilendirilmiştir (Demir, 2012: 14).

Soğuk Savaş sonrası dönemde özellikle Doğu ve Orta Avrupa ülkeleri, içerde ulusal birliklerini geliştirmek, dışarıda ise uluslar arası alanda saygın bir yer edinmek, ülke tanıtımlarını gerçekleştirmek ve uluslar arası birliklere üye olma (AB, NATO) konularında kamu diplomasisi faaliyetleri gerçekleştirmişlerdir. Ancak bu süreçte halen kamu diplomasisinin ana aktörü hükümetlerdir ve amaç ağılıklı olarak uluslar arası tanıtım, siyasal etki oluşturmadır. ABD'nin tek süper güç olarak belirtildiği 1990'dan 2000'li yıllara kadar kamu diplomasisi konusu gerek akademik alanda gerekse uygulama alanlarında fazla ilgi görmemiş, ABD ve Batı'nın Soğuk Savaşı kazanmasının da verdiği rehavetle inmal edildiği belirtilmiştir.Ancak kamu diplomasisi 11 Eylül olaylarından sonra tekrar önem kazanmaya başlamıştır (Szondi, 2008: 3).

Özellikle Irak Savaşları, ABD’nin dünyanın farklı yerlerinde gerçekleştirdiği sert askeri müdahaleler, kitle iletişiminin de sağladığı medya gücüyle Amerikan ve Batı değerlerinin diğer ülkelere ve uluslara tek taraflı sunumunun yarattığı tahribat, 11 Eylül saldırılarına giden süreçte ülkeler arasında artan kültürel çatışmalar, önyargılar, kimlik tartışmaları, göçmen sorunları, bunların neticesinde ortaya çıkan terörizm ve şiddet uluslar arası toplumda kamu diplomasisine duyulan intiyacı tekrar gündeme getirmiştir. Bu sorunların büyük kısmının uluslar arası iletişim ve ilişki kanallarının güçlendirilmesi, kültürel iletişimin arttırılması, anlayış ve işbirliğinin geliştirilmesiyle çözülebileceğine ilişkin görüşler ağırlık kazanmıştır.

Yeni dönemde kamu diplomasisi daha çok iletişimle ve ilişki kurmayla ilişkilendirilmiş, ülkelerin, uluslar arası çevreleriyle iletişim ve ilişki kurma intiyaçlarını karşılayacak potansiyel bir iletişim yöntemi olarak belirtilmiştir. Bu gelişmelere paralel şekilde kamu diplomasisi üzerine yapılan tanımlar da değişmiştir. Yabancı kamuların bilgilendirilmesini, anlaşılmasını, etkilenmesini hedefleyen kamu diplomasisi; bir ülkenin, vatandaşlarının ve kurumlarının yabancı ülkelerin vatandaşları ve kurumları ile diyalogunu genişletmesinde de kullanılır hale gelmiştir. Başka bir deyişle kamu diplomasisi günümüzde hükümetlerin yabancı kamularla iletişimini ve kamulardan kamulara olan iletişimi kapsamaktadır (Krause ve Evera, 2009: 9-10). Tuch'a göre ise kamu diplomasisi, hükümetlerin yabancı kamular nezdinde yürüttükleri; ülkelerinin fikirleri, idealleri, kurumları, kültürleri ve politikaları üzerinde anlayış oluşturmaya çalıştıkları iletişim süreçleri olarak tanımlamıştır (1990: 3).Kamu diplomasisindeki bu paradigma değişimi, davranışsal değişimlerden bilişsel değişimlere, monologdan diyaloga, iknadan ilişki yönetimine, kamuları yönetmekten kamularla ilişsi kurmaya şeklinde tanımlanmıştır (Szondi, 2008:20).

Hükümetlerin kamu diplomasisi süreçlerindeki hakimiyetleri azalırken, başlangıcından günümüze kadar kamu diplomasisinin hedefi konumunda bulunan halklar, sadece etkilenen unsurlar olmaktan çıkıp bu süreçlerin aktörleri haline gelmişlerdir. Tek yönlü olarak gerçekleştirilen, genel kitleleri ikna etmeye ve etkilemeye dönük siyasal iletişim süreçleri yerini çift taraflı, ilişki ve diyaloğu esas alan kişilerarası, kültürlerarası ilişkilerle biçimlenmiş, sivil vatandaşların ağırıkta olduğu iletişim süreçlerine bırakmıştır. Kamu diplomasisi kaynaklarının, mesajlarının ve kanallarının güvenirlikleri sorgulanmaya başlanmış ve kamu diplomasisi güven ve anlayış oluşturma konseptleriyle ilişkilendirilmiştir.

Hükümetlerin doğrudan yönettiği ve hakim olduğu süreçler geçerliliğini yitirirken kamu diplomasisi, sivil toplum alanına doğru genişlemiştir. Kamu diplomasisinin muhatabı olan genel kitleler, hedef kamular şeklinde bölümlenerek, kitlelere yönelik yapılan iletişim, stratejik olarak kurgulanmaya 
başlanmıştır. Kamu diplomasisi, yabancı halklarla iletişime geçme ve hükümetlerin uluslar arası iletişimi olarak tanımlamıştır (Szondi, 2008: 13). Kamu diplomasisinin merkezi konseptini oluşturmaya başlayan ilişki kurma, diğer ülkelerin, kültürlerin, insanların anlaşılması, görüşlerin iletilmesi, yanlış anlaşılmaların düzeltilmesi, ortak noktaların bulunması ile ilişkilendirilmiştir (Leonard ve Alekeso, 2000: 8).

Ülkelerin ve hükümetlerin kamu diplomasisi faaliyetleri yürütmelerinin en önemli nedenlerinden biri uluslararası toplumla iletişim ve ilişki kurma intiyaçlarıdır. Klasik dönemde gerçekleştirilen dış politika ve diplomasi faaliyetleri uluslar arası ilişkilerin devletler düzeyinde yürütülen süreçleri için yeterli iken; günümüzde, hükümet dışı organizasyonlar, sivil toplum kuruluşları, özel sektör kurumları, medya aktörleri ve sivil vatandaşlar ülkelerin imajlarının ve uluslar arası itibarlarının muhatapları haline gelmişlerdir. Uluslararası ilişkiler ve imaj oluşturma faaliyetleri sadece devlet ve hükümet kurumları ve aktörleri tarafından gerçekleştirilmeye çalışıldığında samimiyet, inandırıcılık ve kapsayıcılık konularında şüpheler ortaya çıkmış, dahası bu kadar geniş bir alanı dış işleri ya da hükümet kurumlarının yürütmesi imkansız hale gelmiştir. Kitle iletişim teknolojilerinin çoğalması, ülkelerin hedef kitlelerinin genişlemesine yol açarken, bu kitleleri bilgilendirme ve global konularda hesap verme ülkelerin sorumluluk alanlarından biri haline gelmiştir. Bu yüzden ülkelerin dış iletişimlerinin, imaj yönetimlerinin sadece devlet/hükümet aktörleri tarafından değil sivil toplum ortaklığında yürütülmesi gerektiği vurgulanmaya başlanmıştır.

Ülkelerin ekonomik performanslarını artıran ve gelişmişliği gösteren global markalar, ülkelerin bilinirliliğinde ve imajlarında önem kazanmış, kamu diplomasisi ve yumuşak güç unsuru olarak değer ve kimlik aktarımı gerçekleştiren kanallar haline gelmişlerdir. Örneğin, Amerikan hikayesinin dünyaya anlatılması (telling America's story to the world) şeklinde ifade edilen ve 1990'ı yıllardan sonra Bill Clinton dönemiyle Soğuk Savaşın etkilerini üzerinden atan Amerikan kamu diplomasisi, dayandığı iki temel unsuru ekonomik başarı ve Amerikan çıkarlarının etkileyiciliği şeklinde vurgulanmıştır (Köksoy, 2013: 92). Günümüzde Apple, Google, Microsoft, IBM, Wallmart gibi şirketler bu başarı hikayesinin en önemli unsurlarıdır. 'Marka Diplomasisi - Brand Diplomacy' olarak adlandırılan diplomasi biçimi ulusal kimliğin, değerlerin ve kültürün yabancı halklara/ tüketicilere aktarılmasının önemli bir yolu olarak gösterilmektedir (Szondi, 2008: 24). Global markalar neredeyse dünya nüfusunun yarısına ulaşırken hem kendileri hem de ait oldukları ülkelerle ilgili diğer halklarda olumlu imaj ve sempati oluşturmaktadır.

\section{Kamu Diplomasisi ve Ulus Markalaması İlișkisi}

Günümüzde ürün ve hizmet sağlayıcısı kurumların karşılaştığı en önemli mücadele alanlarından biri dijital teknolojilerle desteklenen, liberal piyasa ekonomisinin ilkeleriyle biçimlenen rekabetçi, yeni pazarlarda diğer ürün ve hizmetlerden farklılaşarak öne çıkmak ve talep görmektir. Ulusal ve uluslar arası piyasalarda yaşanan bu mücadelede, hedef kitlelerin dikkatini çekmenin, onlar tarafından talep görmenin, uzun vadede ise ürüne ve hizmete sadakat yaratmanın en önemli yolunun markalaşma çalışmaları olduğu belirtilmiştir. Başlangıçta özel sektör kurumları için geçerli olan bu farklılaşma intiyacı günümüzde kamu kurumları ve ülkeler için de bir gereklilik haline gelmiştir. Bu gereklilik nedeniyle küçük ölçekte kurumlar büyük ölçekte ise ülkeler reklamcılık, halkla ilişkiler, pazarlama, markalaşma gibi çoklu iletişim kanalları ve yöntemlerini mesaj iletiminde ve siyasal iletişim faaliyetlerinde kullanmışlar, hükümet destekli ve özel kurumların işbirlikleriyle yürütülen ulus markalaması kampanyaları yürütmüşlerdir (Zaharna, 2009: 90). Birçok ülkede (İngiltere, Kanada, vb.) pazarlama ve marka yaklaşımı kamu sektörüne uygulanmış, markalaşma ilkeleri vatandaşlarla daha iyi iletişim ve ilişki kurmada kullanılmıştır (Szondi, 2008: 13). 
Marka kavramı en basit şekilde bir ürün ya da hizmetin tanımlanması ve diğerlerinden ayırt edilmesi amacıyla oluşturulan isim, sembol, işaret, dizayn ya da bunların hepsinin birleşimi olarak tanımlanmışıı(Fan, 2010: 3).Markalama denildiğinde ise marka kimliği yaratmak amacıyla bir dizi pazarlama ve satış faaliyetinin gerçekleştirilmesi; bir tatmin yaşam döngüsü boyunca, müşterinin satın alma ve kullanma deneyimleri için ürün ve hizmetlerin sistematik biçimde tasarlanması, öykülenmesi, medya ile ilişkilerin kurulması ve teknolojinin uygulanması olarak ifade edilmiştir (Moon ve Millison, 2003: 58).Markalama kampanyalarının amacı alıcıların zihninde farklılaşmak ve farklı bir yer edinmek olarak belirtilmiștir (Zaharna, 2009: 90). Bu farklılaşmada amaç bazen diğerlerinden ayrışmak iken bazen de kampanya hedefindeki insanların zihinlerde özel bir yer edinmek ve bunu sürdürmek olarak ifade edilmektedir. Bu amaç bazen olumsuz önyargıları ortadan kaldırma ya da hedef kamuların zihninde yeni ve farklı bir konum elde etmede olabilmektedir.

Şirketlerin ürün ve hizmetleri için uyguladıkları markalaşma konseptleri daha üst bir boyuta taşındığında yer markalaması, ülke markalaması ve ulus markalaması kavramları ortaya çıkmaktadır. Yer ve ülke markalamasında bir yerin tanıtılması ya da bir ülkelerin bazı özelliklerinin(turizm, yatııılar, dışsatım, özel politikalar, vb.) ön plana çıkarılarak, bu alanlarda farkındalık oluşturulması amaçlanmaktadır. Ulus markalaması ise bunlara göre daha kapsamlı stratejilerle marka oluşturma ve pazarlama iletişimi tekniklerinin ulusların imajlarının arttırıması için kullanılması anlamına gelmektedir. Ulus markalaması ile yer markalaması ya da ülke markalaması arasındaki farklar hususunda ilkinin daha genel bir alana (kimlikler, değerler ve kültüre), ikincisinin ise daha özel bir alana (turizm başta olmak üzere bölge ve şehir markalaması konularına) odaklandığı vurgulanmıştır. Bu ayrıma rağmen ulus markalaması ve ülke markalaması birbirine yakın, zaman zaman da birbirinin yerine kullanılabilen kavramlar olarak da belirtilmiştir. Ulus markalaması, yer ve ülke markalaması ile benzerlikler göstermekle birlikte en üst düzey amaç olarak gösterilmiştir (Szondi, 2008: 5).

Ülke markalamasının ve yer markalamasının, ulus markalamasının öncüsü olduğu vurgulanırken, daha çok interdisipliner bir alan olarak pazarlama alanı içinde yer aldığı ifade edilmiştir. Ulus markalaması daha çok kültür, inanç, kimlik vs. soyut unsurlara dayanırken, ülke ve yer markalaması turizm, yatırımlar, ürünler, hizmetler, gibi daha somut ekonomik alanlara vurgu yapmaktadır. (Szondi, 2008: 4). Ulus markalaması, bir hükümet ya da özel kuruluşun, ulusun imajını değiştirme yeteneği için kullandığı etkileme gücü, davranışı, tutumu, kimliği veya ulusun imajını olumlu yönde değiştirmek için kullandığı marka yaratma araçlarına verilen ortak ad olarak tanımlanmıştır (Gudjonsson, 2005: 285).

Kavram, ilk olarak 1996 yılında İngiliz politika danışmanı Simon Anhold tarafından 'nation branding', 'ulus markalaması' adıyla kullanılmıştır. Yer markalaması ve yer pazarlaması kavramları şeklinde kullanımı ise özel bir alan olarak 1990'ların başlarına rastlamaktadır (Szondi, 2008: 5). Benzer şekilde, pazarlama ve marka tekniklerinin partilerin, politikacıların ve politikaların desteklenmesi ve muhatapları nezdinde farkındalık yaratması amacıyla uzun süredir kullanıldığı belirtilmiştir. Bu tekniklerin, 1990 'ı ve 2000'li yıllarla birlikte birçok ülkede yerel hükümet ve kamu sektörü iletişiminin uluslararası politika iletişimi ayağında da etkisini göstermeye başladığı vurgulanmışı ır (Szondi, 2009: 300). Bununla birlikte ülkelerin, 19. yüzyıldan itibaren imaj yönetimine önem vermeye başladıkları belirtilmiş, özellikle dünya fuarlarını, ülkelerin teknolojik yeniliklerini ve ürünlerini diğer ülkeleri ve insanları etkilemek için sergiledikleri birer pazarlama aracı olarak kullandıkları ifade edilmiştir (Szondi, 2008: 3).

Ulus markalaması ulusal imaja vurgu yaparak, bir ulusun kendini diğer uluslara göre farklı bir yere konumlandırmasına dayanmaktadır. Bu nedenle, ulusal imaj yabancı kamuoyu tarafından 
tanımlanmakta ve bu kamuların algısı ise çoğunlukla önyargılardan, klişelerden, medya içeriklerinden ve kişisel tecrübelerden etkilenmektedir (Public Diplomacy and Nation Branding, 2012).Bu nedenle ulus markalamasının, ulus imajlarının yönetimine doğru evrildiği vurgulanmış, kavramın, uluslararası hedef kitleler nezdinde ulus itibarını artırmak için imajların yaratılması, yönetilmesi ve değerlendirilmesini kapsadığı belirtilmiştir (Fan, 2010: 6). Ulus markalaması üzerine yapılan tanımlar incelendiğinde, ulusal kimliklerin yenilenmesi, ulusal rekabetin geliştirilmesi, yurtiçinde ve yurtdışında ekonomik ve kültürel çıkarların korunması, elde edilmesi, ulusal imajın ve itibarın geliştirilmesi ve zenginleştirilmesi gibi konular ön plana çıkmaktadır (Fan, 2010: 4).Ulus markalamasının amacı marka tekniklerini kullanarak ulusların tutumlarının, davranışlarının, ulus imajlarının, ulus kimliklerinin olumlu şekilde değiştirilmesidir (Szondi, 2008: 5).

Ulus markalaması faaliyetlerinin genellikle marka ve pazarlama ajanslarından, danışmanlarından alınan hizmetlerle gerçekleştirildiği belirtilirken, bu danışmanların hükümetlere, ulus markalaması, ülke markalaması ile ilgili ana fikir ve konsept geliştirme, görsel elementler ve ulusal 'marka kitabı' oluşturmada yardımcı oldukları vurgulanmıştır (2008: 12). Ingiliz marka uzmanı Wally Olins'e göre günümüzde şirketler ve ülkeler birbirine benzer özellikler sergilemektedir. Ülkelerin, yatırım, ticaret ve turizm alanlarında rekabet edebilmek için ulusal markalar geliştirme yoluna gittikleri, global şirketlerin ulus inşa etme tekniklerini iç kültürel bağımlılıklar yaratma hususlarında kullandıkları belirtilmiştir (Szondi, 2009: 300). Günümüzde gelişen pazarlama ve markalaşma teknikleri ülkelerin çoğu zaman soyut özellikler barındıran kimlik, değer, kültür ve imaj konularının somutlaştırılmasında, görsel tasarım unsurlarıyla şekillendirilmesinde, bir strateji etrafında sunulmasında ve deneyime dönüştürülmesinde önemli katkılar sunmaktadır.

Kamu diplomasisi ve ulus markalaması, klasik diplomasinin sorunlarla uğraşan yapısına nazaran değerlere, kültüre ve imaja odaklanarak kişiler ve kurumlar için yabancı kamularla iliş̧i ve diyalog sağlamada önemli roller oynamaktadır (Ham, 2007: 136). Bu özelliği nedeniyle ulus markalaması ya da ulus markası denildiğinde kamu diplomasisinin ve yumuşak gücün önemli bir parçası anlaşılmaktadır. Kamu diplomasisi ve ulus markalaması konusundaki ilk çalışmalara, özellikle Soğuk Savaş sonrası dönemde Orta ve Doğu Avrupa'da ortaya çıkan yeni demokratik ülkelerin Avrupa Birliği ve NATO'ya üyelik süreçlerinde, Soğuk Savaş dönemi Komünist geçmişlerinden ve politik imajlarından kurtulma amaçlı kampanyalarında rastlanmaktadır. Ancak o dönemlerde bu iki alan arasında bir bağ kurulmamış ve çalışmaların birlikte koordine edilmesi fikri gelişmemiştir (Szondi, 2008: 16).

Kamu diplomasisi ve ulus markalaması ilişkisi denildiğinde öne sürülen görüşler iki ana başlık altında değerlendirilebilir. İlk görüş, iki alanın tamamen birbirinden bağımsız alanlar olduğu ve aralarında bir ilişki bulunmadığı yönündedir. Diğer görüş ise iki alanın benzer konseptler içerdiği, birbirine entegre edilebileceği hatta iki kavramın aslında aynı şeyi ifade ettiği şeklindedir (Szondi, 2008). Illk görüşü savunan yazarlara göre kamu diplomasisi faaliyetleri çoğu zaman 'ulus markalaması' olarak çevrilen 'nation branding' faaliyetleriyle karıştııılmaktadır. Kamu diplomasisi, ulus markalamasına göre daha geniş bir alanı kapsamaktadır. Ulus markalaması genel kitlelere, ağırlıklı olarak olumlu imajların tek yönlü olarak sunulmasına amaçlarken, kamu diplomasisi hedef kitleleri bölümleyerek çift yönlü bir iletişim ve diyalog sürecini oluşturmayı hedeflemektedir (2008: 16). Örneğin, kamu diplomasisi kültürel ve politik olarak daha özel grupları hedeflerken, ulus markalaması genel kitlelere genel imajlarla ulaşmaya çalışmaktadır (Public Diplomacy and Nation Branding, 2012). Ulus markalamasının pazarlama ile iç içe geçtiği, ekonomik amaçlar taşıdığı, genel imajlara ve sembollere dayandığı belirtilirken kamu diplomasisinin, uluslararası ilişkiler ve uluslararası iletişim sistemi içinde yer aldığı, çoğu zaman politik amaçlar etrafında şekillendiği vurgulanmıştır (Szondi, 2009: 302). İki alan arasındaki farklııklar, hedefler ve sonuçlar 
ile birlikte, dış politikaya, yöntemlere, iletişime, yönetime, dil ve kültür türlerine karşı artan ilginin ülke lehine kullanılması konusunda izlenen yöntemleri içermektedir (Erzen, 2012: 112).

İkinci görüşe göre ise kamu diplomasisi ve ulus markalaması, imaj yaratımı, sembol üretimi, ilişki inşa etme ve kitle iletişimini yoğun olarak kullanma konularında benzerlikler taşımaktadır (2012: 112). Kamu diplomasisinin ulus markalamasının bir parçası olduğu öne sürülürken benzer şekilde ulus markalamasının kamu diplomasisinin bir parçası olduğu da öne sürülmüştür (Szondi, 2008: 19). İki alanın amaçları ve kullandıkları araçlar söz konusu olduğunda ilişkileri daha da netleşmektedir.Kamu diplomasisi ve ulus markalaması amaç ve stratejiler bakımından birbirine benzer özellikler taşımaktadır (Rawson, 2007: 215). Her iki alan da ülkelere olumlu bir imaj, bu imajı destekleyecek ve marka algısını güçlendirecek semboller, dış politika, turizm, dış yatırımlar gibi alanlara uygun ortamlar yaratacak bir ilişki sistemi oluşturmayı amaçlamaktadır. Benzer şekilde iki alan da ülkelere stratejik amaçlarına ulaşmada ilişki kurma ve cazibe yaratma fırsatları sunmaktadır. İki alan yumuşak gücün de önemli unsurları olarak kabul edilmektedir (Public Diplomacy and Nation Branding, 2012). İster kamu diplomasisi ulus markalamasının parçası olsun isterse de ulus markalaması kamu diplomasisinin bir parçası olsun pratikteki uygulama, bilgilerin stratejik olarak tasarlanması ve dağıtıımasına dayanmaktadır (Zaharna, 2009: 90).

Ulus markalamanın önde gelen savunucularından Simon Anholt, hükümet iletişimi olarak nitelendirdiği kamu diplomasisini, ihracat, turizm ve direkt yabancı yatırımın yanı sıra ulus markalamayı tamamlayan ve güçlendiren dördüncü bir boyut olarak belirtmiştir (Zaharna, 2009: 90). Benzer şekilde ülke markalamasının üç alanda gerçekleştiği belirtilmiştir. Bunlar marka ihracı, dış ülkelere direk yatırım ve turizm olarak sıralanmaktadır (Erzen, 2012: 113).Bu görüşlere göre turizm faaliyetleri, ihraç edilen ürün ve hizmetler, dış yatırımlar ülke markalamasının en önemli unsurları olarak ön plana çıkmaktadır. Anholt'un da belirttiği gibi bu unsurlara bir dördüncü bir boyut olarak eklenen kamu diplomasisi, yabancı halklarla toplam iletişimin yönetilmesi ve sürdürülmesi açısından önem taşımaktadır. Ulus markalamasını kamu diplomasisinin bir parçası olarak gören yaklaşıma göre ulus markalaması yabancı halklara ve uluslara ulaşmak için kamu diplomasisinin bir aracı olarak görülmektedir (Szondi, 2008: 23) Bu görüşü destekler şekilde kamu diplomasisi, hükümet tarafından ulusal markanın ve kimliğin yönetilmesi olarak tanımlanmıştır (Potter, 2009: 6). Hükümetlerin bu sahipliği kamu diplomasisi ile ulus markalaması konseptlerini birbirine bağlamaktadır.

Ulus markalaması kavramı,doğrudan hükümetlerle ilişkilendirilmezken genellikle hükümetler ulus markalaması süreçlerinde öncü ve koordinatör rolü oynamaktadır. Benzer şekilde yeni kamu diplomasisi anlayışında hükümetler başat unsurlar değil koordinatör aktörler olarak yer almaktadır. Ulus markalaması uygulayıcıları hükümetlere koordinasyon ve daha kapsamlı yaklaşımlar geliştirilmesi konularında ihtiyaç duyulduğunu belirtmişlerdir (Szondi, 2008: 12). İki alanın aktörlerinin sivilleşmesiyle hedef kamularındaki farkıılık da artmıştır. Özellikle ülke vatandaşlarının, ulus markasının canlı elçileri olarak ulusal gururu ve amaçları gerçekleştirmede özel bir yerinin olduğu vurgulanmıștır (Public Diplomacy and Nation Branding, 2012). Bu nedenle, ulus markalamasının hedef kitlesi hem iç kamular hem de dış kamulardır. Ulus markalaması için aynı öneme sahip bu iki kitle, şirket çalışanlarının markayı yaşama ve marka elçisi olma misyonuyla benzerlikler taşımaktadır. Vatandaşlar, ulusun kimliğinin, değerlerinin, kültürünün taşıyıcıları ve temsilcileridir.

Ulus markalaması kampanyalarıyla vatandaşların, ortak amaçlar etrafında bir araya getirilebileceği, ulusun ortak gururu yaşamasına olanaklar oluşturulabileceği belirtilmiştir (Szondi, 2008:2). Benzer şekilde, kamu diplomasisi de sadece yabancı halkları değil, dış politikanın oluşturulması 
(engaging approach) ve dış politikanın anlatılması (explaining approach) konularından iç kamuları hedeflemektedir (Szondi, 2008: 6). Hem kamu diplomasisi hem de ulus markalaması alanlarında hükümet dışı aktörlerin ve sivil inisiyatiflerin etkinliği göz önünde tutulduğunda ülkelerin sahip oldukları değerlerin, politikaların ve mesajların sahibi doğrudan o ülkenin vatandaşlarıdır. Ülke vatandaşlarının sahiplendiği değerlerin ve politikaların yabancı halklara daha kolay anlatılacağı, daha kolay anlaşılacağı ve oluşturulmak istenen imajın bütünlüğüne katkı sağlayacağı vurgulanmaktadır.

İki alanın ilişkisinin en belirgin şekilde ortaya çıktığı bir diğer konu ise iletişim ve ilişki kurma fonksiyonlarıdır. Kamu diplomasisi ve ulus markalaması kimlik oluşturma, imaj yaratma, değer aktarımı ve kültürel diplomasi konularında ortak amaçlara dayanırken ilişki kurma konsepti iki alan için de merkezi bir kavram haline gelmektedir (Szondi, 2008: 6). Szondi, iki alanı uluslar arası halkla ilişkiler adı alında kavramsallaştırmıştır. Bu nedenle iletişim (kamu diplomasisi) ve imaj oluşturma (ulus markalaması) kavramlarının yerine merkezi bir kavram olan ilişki kurma konsepti önerilmiştir (Szondi, 2008: 27). Bazı yazarlara göre iki kavram aynı şeyi ifade etmektedir. Öyle ki; kamu diplomasisi, ülkelerin marka iletişimleri anlamına gelmektedir (Mengü ve Yıldırım,2012: 72). İki alan da ilişki kurucu işlevler taşımakta, stratejik öz tanıtımı gerçekleştirmekte ve uluslararası ilişkileri de kapsayacak şekilde çift taraflı iletişim fırsatları sunmaktadır. Farklı konseptler de benzer özellikler taşımaktadır (Public Diplomacy and Nation Branding, 2012). Szondi'ye göre ülke tanıtımı ve olumlu imaj yaratma konularında aynı faaliyetleri kapsadığı belirtilen iki alan erken dönemde aynı anlama gelecek şekilde kullanıımıştır (2008: 30).

Yazarın, Orta ve Doğu Avrupa ülkeleri özelinde yaptığı çalışmada ulusal itibar yönetiminin alt başlıkları birbiriyle ilişkili ve birbirini destekler şekilde yer markalaması, ülke (ulus) markalaması, kültürel diplomasi ve algı yönetimi olarak sıralanmıştır. Ülkelerin itibar yönetimlerinin parçaları olan bu alanlar daha alt başlıklarda yer markalaması (turizm), ülke-ulus- markalaması (ekonomi politikaları), kültürel ilişkiler-kültürel diplomasi (kültürel miras, dil, sanat, film, vb.), kamu diplomasisi (dış politika ve dış ilişkiler), algı yönetimi (ülkenin içerde ve dışarıdaki etik politikaları, davranışları, imajları) olarak belirtilmiştir.Ülke-ulus markalaması, kültürel diplomasi ve kamu diplomasisi ile ilişkili kavramlar olarak gösterilmiş ve üçünün toplamının ülkelerin itibarını oluşturduğu vurgulanmıştır (Szondi, 2009: 297).

Eski ve yeni kamu diplomasisi yaklaşımları incelendiğinde yeni kamu diplomasisi yaklaşımının ve terminolojisinin, kurumsal markalaşma, ilişki teorisi, ulus markalaması kavramları etrafında şekillendiği vurgulanmıştır (Cull, 2009: 13). Ülkelerin yürüttükleri kamu diplomasisi ve ulus markalaması faaliyetlerinin genel olarak amaçları, olumlu imajların yaratılması, güçlendirilmesi, geliştirilmesi, olumsuz imajların ortadan kaldırılması, yabancı hedef kamularla iyi ilişkiler kurulması, bu ilişkilerin sürdürülmesi, saygınlığın ve itibarın arttırılması ve başta dış politika olmak üzere siyasi, ekonomik ve kültürel amaçlara ulaşmayı kolaylaştıracak iklimlerin yaratılması olarak sıralanmaktadır. Koschwitz, kamu diplomasisinin uygulanma sebeplerini bilgi değişimi, önyargıların azaltılması, hükümetlerin kendi dış politikaları ve toplum modelleri için sempati yaratılması, tanıım ve imaj oluşturulması olarak sıralamıştır (Signitzer ve Coombs, 1992: 137147).

Ülkelerin iç ve dış kamularının, halklarının çeşitliliği ve enformasyona erişim güçleri göz önünde tutulduğunda ulus markalaması çalışmaları bir deneyim ve diyalog sürecinden oluşmakta, sonuçlarının etkinliği insanlar arasındaki gerçek zamanlı iletişime ve ilişkiye dayanmaktadır. Kamu diplomasisi ve ulus markalaması arasındaki bağlantılar iki alanın benzer amaçlar taşıdığını ve benzer konseptlere dayandığını göstermektedir. Her iki kavram da ülkelerin dış imajları ve 
iletişimleri ile ilişkili bulunmuştur. İki alandaki çalışmaların amacı ülkelerin, uluslar arası halklarla, kamuoylarıyla iyi ilişkiler kurması ve olumlu imajlar oluşturmasına dayanmaktadır. Pazarlama ve markalama alanından gelen ulus markalaması kavramı kamu diplomasisine göre daha dar ve kısıtlayıcı özellikler taşırken, hükümetler ve dış işleri için önemli bir alan haline gelen, sivil alana doğru genişleyen kamu diplomasisi arasındaki ilişki gün geçtikçe gelişmekte; ekonomik, sosyal ve kültürel alanlardaki değişimlerle yeni boyutlar kazanmaktadır (Szondi, 2008: 38).Esas olarak ülkelerin dış iletişimlerinin ve imajlarının yönetildiği bu iki alanın birlikte değerlendirilmesi ve koordine edilmesi ülkelere, diğer ülkelerle ve halklarıyla kurulacak ilişkilerde stratejik ve kapsamlı iletişim olanakları sunacaktır.

Ülkelerin siyasi, ekonomik, kültürel ve sosyal hedeflerini gerçekleştirmek için bu ilişkinin ve iletişimin gerekliliği günümüz uluslar arası ilişkiler sisteminin en önemli gerekliliği haline gelmiştir. Bu ilişkinin ve iletişimin kurulamadığı durumlarda ülkeler hakkındaki imajlar ve algılamalar, farklı zamanlarda yapılan tanıtım faaliyetlerine,tarihsel önyargılara, söylentilere ve kitle iletişimi ve özellikle de günümüzde kişiselleştirilmiş sosyal medya aracılığıyla dolaşıma giren imaj ve fikirlere göre şekillenecektir. Kamu diplomasisi ve ulus markalaması faaliyetlerinin gerçekleştirildiği uluslar arası ilişki ve iletişim alanlarının dizaynı ve faaliyetlerin koordinasyonu oluşturulmak istenen marka algısının ve imajının bir gerekliliği durumundadır. Bu yüzden ülkelerin yürüttüğü kamu diplomasisi faaliyetleri stratejik iletişime ve ilişki kurma konseptine dayanmalı, ulus markalaması çalışmaları bu anlayışa hizmet eder şekilde kurgulanmalıdır.

\section{Kamu Diplomasisi Perspektifinin, Türkiye Ulus Markalamasına Katkısının Değerlendirilmesi}

Ülkelerin ve hükümetlerin diğer ülke halklarıyla ilişkilerinin yönetimi olarak adlandırılan kamu diplomasisi kavramı ve faaliyetleri, ülkelerin marka imajlarını ve algılarını doğrudan etkilemektedir. Bu faaliyetler marka vaadinin tutarılığını yansıtırken aynı zamanda hedef kitleler ya da özel kamular için bu vaatleri deneyimleyebilecekleri iletişim olanakları sunmaktadır. Kamu diplomasisinin, ulus markalamasına doğrudan faydası hem stratejik bir iletişim konsepti sunması hem de çok boyutlu faaliyet alanlarıyla ulus markasının vaatlerinin imaj olarak yaratımasına ortamlar sağlamasıdır. Kamu diplomasisi teknik ve uygulamaları, ülke markalaması sırasında intiyaç duyulan bilgilerin stratejik olarak tasarlanması ve dağıılımasına yardımcı olmaktadır. Ülke markası inşasında kamu diplomasisinin değerlere odaklandığı, bireysel ve kurumsal ilişkilerin ve diyalogun tesis edilme sürecine önem verdiği belirtilmiştir (Özkan, 2014).

İki alan arasındaki ilişki özelinde kamu diplomasisi perspektifinin, ulus markalamasına katkısını değerlendirmek için Türkiye'deki kamu diplomasisi ve ulus markalaması konularına kısaca göz atmak gerekir. Günümüzde, Türkiye'deki kamu diplomasisi anlayışına ve kurumsallaşmasına bakıldığında kavrama ve uygulamaya ilişkin farkındalığın gün geçtikçe arttığı görülmektedir. Ancak gerek kavramın gerekse kurumsallaşmanın çok yeni olması nedeniyle stratejik derinlikten ve yapılanmadan yoksun olduğu belirtilmektedir.Türkiye'de yaptıkları faaliyetleri doğrudan kamu diplomasisi adı alında icra etmeseler de faaliyetlerinin nitelikleri gereği dolaylı olarak 'Türkiye Kamu Diplomasisi'2anlayışını destekleyen kamu kurumları, Cumhurbaşkanlığı, Başbakanlık, Dışişleri Bakanlığı, Türkiye Radyo Televizyon Kurumu (TRT), Kültür ve Turizm Bakanlığı, Milli Eğitim Bakanlığı, Avrupa Birliği Genel Sekreterliği (ABGS), Yurtdışı Türkler ve Akraba Topluluklar Başkanlığı, Türk İşbirliği ve Kalkınma İdaresi Başkanlığı (TiKA), Basın Yayın ve Enformasyon

2 'Türkiye Kamu Diplomasisi' kavramı bu haliyle literatürde ilk defa kullanılmıştır. Kavram, kamu diplomasisinin ruhuna uygun olarak Türkiye vatandaşlarının genelini kapsayacak bir kamu diplomasisi anlayışını tanımlamaktadır. 
Müdürlüğü, Kamu Diplomasisi Koordinatörlüğü (KDK), Anadolu Ajansı (AA), Başbakanlık Tanıtım Fonu ve benzer faaliyetler yürüten diğer bağlı kuruluşlar olarak sıralanmıştır (Köksoy, 2013:184).Kızılay, Afet ve Acil Durum Yönetimi Başkanlığı (AFAD), Başbakanlık Yatııım Destek ve Tanıtım Ajansı (TYDTA-Invest in Turkey), Diyanet İşleri Başkanlığı, Yunus Emre Enstitüsü, vb. birçok kurum da bu kapsamda değerlendirilebilir. Bu kurumlara kamu diplomasisinin sivil tarafını oluşturan sivil toplum kuruluşları, insani yardım kuruluşları, özel eğitim kurumları, özel şirketler, kültür- sanat kurumları, medya ve basın kurumları, kanaat önderleri ve vatandaşlar da eklenmektedir.

Bukurumlarveaktörler, Türkiye'nin uluslararası toplumlailişkilerini kurarken Türkiye'nin uluslar arası kamuoyu nezdindeki marka imajını da oluşturmaktadır. Türkiye'nin kamu diplomasisi kurumlarını ve aktörlerini oluşturan bu yelpazeyi daha da genişletebiliriz. Kamu diplomasisinin etkinlik alanına paralel şekilde süreçte yer alan kurumlar ve aktörler de genişlemekte ve artmaktadır. Türkiye'de kamu diplomasi anlayışının yerleşmesi, kurumsal temsilinin ve koordinasyonun sağlanması amacıyla hali hazırda Basın-Yayın ve Enformasyon Genel Müdürlüğüne bağlı olan Kamu Diplomasisi Koordinatörlüğü (KDK) 2010 yılında kurulmuş ve kuruluş amacı kamu diplomasisi konusunda görevli kurumlar arasında daha etkin bir koordinasyonun sağlanması, yakın işbirliği ve hızlı karar alma süreçlerinin gerçekleştirilmesi olarak belirtilmiştir (KDK Genelgesi, 2010).

Kurumun vizyonunda, günümüz uluslararası ilişkiler sisteminin karışıklığından bahsedilirken kamu diplomasisinin, bu durumda uluslararası kamuoyunu etkilemenin ve yönlendirmenin en önemli araçlarından biri haline geldiği vurgulanmaktadır. KDK'nın amacı vizyonunda "...bu çerçevede gerek ülkemizin güçlü mirasını ve çağdaş tecrübesini gerekse son yıllarda bölgesel ve küresel siyasette artan etkisinden yola çıkarak, Türkiye'nin yeni hikayesini etkin bir şekilde anlatmayı, farklı kesimlerle diyaloğa geçmeyi ve çok-taraflı bir iletişim ekseninde faaliyet yürütmeyi amaçlamaktadır." şeklinde belirtilmiştir (KDK, 2015).

Kurumun misyonunda ise kamu diplomasisinin, Türk dış politikasının ve yumuşak güç kapasitesinin en önemli araçlarından biri olarak görüldüğü vurgulanmış, bu yolla, Türkiye'nin uluslararası kamuoyunda görünürlüğünün ve etkinliğinin arttırılmasının hedeflendiği belirtilmiştir. Ayrıca KDK'nın görevi, Türkiye'nin doğru ve etkin bir şekilde tanınması ve bilinmesi için kamu kurumları ile sivil örgütlenmeler arasındaki koordinasyonu sağlamak olarak ifade edilmiş, Türkiye'nin tanıtımında ve algı yönetiminde merkezi öneme sahip olan alanlar (diplomasi, dış yardımlar, bilim ve teknoloji, ekonomi, yüksek öğretim, turizm, kültür, sanat ve medya vb.) kamu diplomasisi faaliyet alanları olarak adlandırılmıştır. Son olarak KDK'nın bu farklı faaliyet alanlarının koordinasyonunu sağlayarak Türkiye'nin stratejik iletişimine ve etkin tanıtımına katkıda bulunacağı vurgulanmıştır (KDK, 2015).

Kurumun faaliyet kapsamına ve kurumsal yapısına bakıldığında bu faaliyetler, kamu diplomasisi ve dış politika konularında gençlerin bilgilendirilmesini amaçlayan üniversite programları, aralarında akil insanlar ve uzman kişilerin bulunduğu, siyasal iletişim faaliyetleri olarak değerlendirilen toplantılar, paneller ve konferanslar, gazeteci heyetlerinin gezilerinin, medya bilgilendirmelerinin, kültürel ve tanııı faaliyetlerinin yer aldığı medya tanıtım çalışmaları olarak belirtilmiştir. Kurumun web sayfasında ağırlıklı olarak bu faaliyetler ile ilgili duyurular, bilgilendirmeler ve Türk dış politikası ve diğer kurumlarının uluslar arası faaliyetleri ile ilgili haberler yer almaktadır. Kurum doğrudan Başbakanlığa bağııken, Koordinatörlüğün toplam 17 personeli bulunmaktadır (KDK, 2015).

Türkiye kamu diplomasisi için bir milat olarak değerlendirilebilecek bu yapılanma önemli olmakla 
birlikte, hem kurumun yapısı ve kapasitesi hem de yürüttüğü faaliyetler göz önüne alındığında vizyon ve misyonda belirtilen Türkiye'nin kamu diplomasisi stratejisinin oluşturulması, dış iletişiminin yönetilmesi ve bu alanda faaliyet gösteren, Türkiye'nin imajını belirleyen kurumlar arasında üst düzey bir koordinasyonun sağlanması konularında yetersiz kalmaktadır.Türkiye kamu diplomasisi anlayışının gerekleri göz önüne alındığında hali hazırda yukarıdaki devlet/ hükümet ve sivil toplum kurumlarını koordine edecek, faaliyetleri ortak amaçlar etrafında planlayacak, sonuçlarını değerlendirecek, Türkiye'nin genel kimlik, değer, kültür imajlarını oluşturacak ve iletişimini yönetecek bir yapı bulunmamaktadır.

Kurumlar arasındaki işbirliğinin ve koordinasyonun sağlanacağı üst yapıların oluşturulması, Türkiye kamu diplomasisi anlayışının stratejik bir yapı kazanmasına, bütüncül bir bakış açısıyla değerlendirilmesine ve Türkiye'nin yabancı halklarla ilişkilerini ve iletişimini yönetmesine imkan sağlayacaktır (Köksoy, 2013:4). Ayrıca, KDK'nın doğrudan başbakanlığa yani hükümete bağlı olması yeni kamu diplomasisi anlayışıyla uygunluk taşımamaktadır. Bu iki açıdan kısıtılıı oluşturmaktadır. Hem hükümet dışı parti ve görüşlerin temsilinin sağlanmasını engelleyecek hem de kamu diplomasisi politikalarına doğrudan hükümet politikalarının ve parti politikalarının yansıması intimali karşısında siyasal nedenlerle bu politikalara güvensizlik doğacaktır. Kamu diplomasisi ve süreçleri bir ülkenin toplam imajını ve itibarını oluşturacağından tüm görüşleri temsil edecek partiler üstü seviyede konumlandırılmalıdır.

Türk dış politikası, 1990'lı yıllarda başlayan değişimle birlikte Soğuk Savaş dönemindeki statik politikalardan uzaklaşarak, uluslararası ilişkilerde aktif oyun kurucu ülke olmaya dönük politikalar izlemektedir. Genel olarak 2000'li yıllardan sonra izlenen dış politika, bölgesel politikalarda üst düzey siyasi diyalog, herkes için güvenlik, karşılıklı ekonomik bağımlılık ve çok kültürlülüğün korunması olarak belirlenen dört prensibe bağlı olarak gelişmiştir. (Zengin, 2010). Bu paradigma değişimine bağlı olarak Türkiye'nin başta komşu ülkeler olmak üzere diğer ülkeler ve halklarla ilişkileri artmış, klasik dış politika ve diplomasi yöntemlerinin bu ilişkileri yönetmekte yetersiz kaldığı anlaşıımışıı.Bu intiyaca paralel şekilde kamu diplomasisi konusunda adımlar atılmıştır.

- Türkiye'nin değişen dış politika anlayışını yansıtan ve esas olarak Türkiye kamu diplomasisinin kapasitesini oluşturan faaliyet alanları şu başlıklar altında değerlendirilmiştir.

- Devletler ve hükümetler arası siyasal iletişim faaliyetlerinin gerçekleştirildiği çoğunlukla devlet ve hükümet aktörlerinin aktif rol aldığı alanlar.

- Uluslararası barışa katkı ve sorunların sürekli müzakereler yoluyla çözülmesine yönelik faaliyetlerin gerçekleştirildiği diyalog ve müzakere alanları.

- Kültür, eğitim ve sanat faaliyetlerinin gerçekleştirildiği kültürlerarası diplomasi faaliyetlerinin uygulandığı alanlar.

- Sosyal sorumluluk ve insani yardımların uygulandığı, toplumlar arasında yardımlaşma ve işbirliğinin gerçekleştirildiği alanlar.

- Çoğunlukla özel şirketlerin yürüttüğü ekonomik ilişkiler aracılığıyla ticari etkileşimin yoğunlaştığı alanlar.

- Kitle iletişimi ve yayıncılık faaliyetleri aracılığıyla tanıım, haberleşme ve enformasyon alışverişinin gerçekleştiği alanlar(Köksoy, 2013: 215-233). 
Bu alanları ve faaliyetleri genişletmek mümkündür. Kamu diplomasisi özü gereği insanları ve ilişkide olduğu tüm özel ve tüzel kişileri ve onların faaliyetlerini kapsamakta, ülkelerin resmi siyasal ilişkileri ve onların dışında kalan bütün alanlarla bağlantılar kurmaktadır.

Türkiye'de ulus markalaması çalışmaları denildiğinde bu çalışmaların en azından şimdilik akademik bir çerçevede ele alınmadığı pratikteki uygulamaların ise genellikle ekonomik ve kalkınma amaçı yer markalaması ve ülke markalaması kavramları etrafında şekillendiği görülmektedir. Ancak uluslar arası ilişkiler alanında Türkiye’nin gerçekleştirdiği siyasal, ekonomik, kültürel ve sosyal gelişmelerin doğrudan ulus ve ülke imajına yansımaları olduğu belirtilmiştir. Bu hususu 'Türkiye Markası' kavramı etrafında değerlendiren Wally Olins, Türkiye'nin son yıllarda ekonomik, politik ve kültürel politikalar çerçevesinde gerçekleştirdiği çalışmaların hâlihazırda ülkenin marka değerini artırdığını vurgulamış ancak bu çalışmaların anlaşılır bir çerçeveye oturtulamadığını, Türkiye'nin tutarlı ve ulusal bir markalaşma politikasına ciddi anlamda intiyaç duyduğunu belirtmiş̧tir (Brandage, 2012) Benzer şekilde Özkan, Türkiye'nin uluslararası alanda kendini anlatamadığını, tanıtamadığını, geçmişteki olumsuz ve negatif algısını düzeltecek etkili ve kalıcı girişimlerde bulunamadığını vurgulayarak Türkiye'nin “ülke markasını" inşa etmeye intiyacı olduğunu ifade etmiştir (Özkan, 2014).

Türkiye, kamu diplomasisi alanındaki gelişmelere benzer şekilde son yıllarda ülke markası yaratma konusunda da bazı önemli adımlar atmaktadır. Bunlar çok kapsamlı ve ulus markalaması düzeyinde olmasa da özel alanlardaki markalaşma çalışmalarına örnek olabilecek niteliktedir. Bu çalışmalar iki örnek çalışma üzerinden değerlendirilebilir. Ilki, amacı, global markalar yetiştirerek Türkiye'nin inracat gelirlerini ve geliştirilecek Türk markaları sayesinde 'Türk Malı' imajını uluslararası bir boyuta taşıyarak Türkiye'nin itibarını artırmak olan 'Turquality Projesi'dir. Global marka olma potansiyeli taşıyan firmalara destek olmak amacıyla geliştirilen proje ' 10 Yılda 10 Dünya markası yaratmak' vizyonuyla ve dünyanın devlet destekli ilk ve tek markalaşma programı olarak sunulmuştur (Turquality, 2015).

Dayanıklı tüketim ürünleri, endüstriyel makina, hazır giyim, kuyum/mücevherat, otomotiv ve tekstil gibi sektörlerdeki firmalara markalaşama hizmeti veren proje, Ekonomi Bakanlığı, Türkiye İhracatçılar Meclisi ve İhracatçı Birlikleri'nin ortak girişimiyle kurulmuş, sertifikasyon ve yönetim süreçlerinde yabancı şirketlerden danışmanlık hizmeti alınmıştır. (Turquality, 2015). Proje genel olarak hem Türkiye'nin ekonomik ve dış yatırım kapasitesini artırmaya hem de global markalar yoluyla Türkiye'nin dış imajını geliştirmeye çalışmıştır.Günümüzde 'Marka Diplomasisi - Brand Diplomacy' olarak adlandırılan diplomasi biçimi ulusal kimliğin, değerlerin ve kültürün yabancı halklara/ tüketicilere aktarılmasının bir yolu olarak gösterilmektedir (Szondi, 2008: 24). Bir ülkenin sahip olduğu ulusal markaların yabancı halklarla kurulacak ilişki yönetimi için gerekli olan ilk adımı atacağı, bu markaların tüketicileri markanın menşe ülkesine de sempati ile yaklaşacağı vurgulanmıştır (Sancar, 2015)

Türkiye'de ülke markası konusunda geliştirilen bir diğer proje ise yine devlet ve iş dünyası ortaklığında yürütülen 'Turkey - Discover The Potential / Türkiye-Gücünü Keşfet' sloganıyla sunulan 'Türkiye Markası' çalışması olmuştur. Turquality Projesi'ne benzer şekilde Ekonomi Bakanlığı ve Türkiye İhracatçılar Meclisi'nin (TiM) koordinasyonunda başlatılan 'Türkiye Markası' çalışmaları, Türkiye'nin kendi değerlerini ortak bir markada buluşturarak tanıtım yapma ve küresel rekabette avantajlı hale gelme misyonundan hareketle gerçekleştirilmiştir (Genelge, 2015). Proje kapsamında tasarlanan, geleneksel kilim, mimari, el sanatları gibi alanlarda kullanılan 8 ayrı motiften esinlenerek geliştirilen logonun Türkiye'nin tüm ihraç mallarında ve tanıtım materyallerinde kullanılacağı belirtilmiştir. 
Ayrıca tüm uluslararası etkinliklerde (kamu/özel tüm kurum ve kuruluşlar tarafından gerçekleştirilecek ulusal ve uluslararası sosyal, ekonomik, ticari, kültürel, sanatsal, sportif vb. faaliyetlerde, mekânlarda ve Komite tarafından uygun görülen diğer alanlarda)kullanılması ve 'Türk Malı' algısının uluslar arası kamuoyunun zihnine yerleştirilmesi hedeflenmiştir (TiM, 2014). Projenin takibi ve sürecinin gerçekleştirilmesi için 'Türkiye Markası İzleme Komitesi' oluşturulmuş ve komitede Ekonomi Bakanlığı Müsteşarının başkanlığında; Bilim, Sanayi ve Teknoloji, Dıșişleri, Gençlik ve Spor, Gümrük ve Ticaret, Kültür ve Turizm ile Sağlık Bakanlığı, Türk İşbirliği ve Koordinasyon Ajansı, Türkiye Yatırım Destek ve Tanııı Ajansı, Yurtdışı Türkler ve Akraba Topluluklar Başkanlığı, Yunus Emre Enstitüsü, Dış Ekonomik İlişkiler Kurulu, Türkiye Odalar ve Borsalar Birliği ile Türkiye İhracatçılar Meclisi üyeleri yer almıştır (Genelge, 2015). Projede oluşturulan logo aracılığıla yabancı kamuoyuyla iletişim kurulması amaçlanmış ve uluslar arası topluma Türkiye'nin potansiyelini ve gücünü keşfetmesi konusunda bir davet yapılmıştır.

Her iki çalışmanın da amacı, Türkiye'nin ekonomik ve dış yatırım kapasitesinin arttırılması ve yaratılacak markalar ve markalaşma konseptleri aracılığıyla Türkiye'nin dış imajının ve algısının geliştirilmesi olmuştur. 'Türk Malı' algısının yükseltilmesi ve Türkiye'nin markalar ve ürünler aracılığıyla dünyaya tanıtılması, marka diplomasisine güzel bir örnek niteliğindedir. Bu çalışmaların ekonomik ve dış satım olarak Türkiye'nin ekonomik gelişmesine ve imajına önemli katkılar sağladığı belirtilmektedir. Ancak daha üst seviyede 'Türkiye Markası'ndan ya da 'Türkiye Ulus Markalaması'ndan'3 bahsedilecek olursa bu çalışmaların Türkiye'nin genel imajını ve saygınlığını oluşturmaktan uzak olduğu, uluslar arası alanda karşılaştığı algı ve iletişim sorunlarını çözemeyeceği anlaşılabilir. Bu tarz ekonomik gelişmeyi önceleyen yer ve ülke markasına yönelik çalışmalar ülke imajına ve algısına katkı sağlarken daha üst stratejik amaçlara, ulus markalamasına hizmet etmediği sürece uzun soluklu etkiler oluşturamamaktadır.

Benzer bir görüşü dile getiren Olins, 'Türk Malı' algısının yurt dışında istenilen seviyede olmadığını belirtmiş, insanların, ileri teknoloji ve yüksek katma değere sahip ürünleri düşündüklerinde, Türkiye'nin bir marka veya bir üretici olarak akıllarına gelmediğini vurgulamıştır.Bunun yanı sıra Türkiye'nin "bir turizm markası" olarak son derece saygın bir marka olduğunu ifade etmiştir (Brandage, 2012). Tuncer, bu konuda 'Türkiye'nin tanıtımı' söyleminin bırakılması gerektiğini ve yapılan hatanın 'tanıtım yanlışından' 'markalaşma stratejisi' ne adım atılamamasından kaynaklandığını belirtmiştir. Tuncer'in 10 yıl önce yaptığı bu eleştiri günümüzde halen geçerliliğini korumaktadır. Türkiye tanıtımının turizm, yatııım ve dışsatım tanıtımlarıyla kısıtı kaldığı vurgulanmış, bunun bir ülkenin ülke markası hakkında genel bir strateji oluşturamayacağı sadece büyük stratejinin bir parçası olabileceği ifade edilmiştir (Tuncer, 2005).

Erzen'e göre bir ülkenin markalaşmasının öneminin ne olduğunun anlaşılması için ne olmadığının anlaşılması gerekmektedir. Buna göre, ülke markalaşması, sadece turizmi tanıtmaktan ibaret değildir, sadece logodan ibaret değildir, tanıtım reklamlarının yayınlanmasından ibaret değildir, sadece yabancılara yönelik değildir, kısa vadeli proje değildir, bir ülkenin markalaşması kurumsal markalaşma gibi düşünülmemelidir (Erzen, 2012: 114). Özkan, konunun bütüncül bir yaklaşımla değerlendirilmesi gerektiğini vurgulamış, ülke tanıtımının, kamu diplomasisi bakış açısıyla gerçekleştirilmesinin; ülkenin bilim, sanat, kültür, spor, iş dünyası, üniversiteleri vb. değerleri ile birlikte değerlendirilmesinin, ülkenin tanııımının yapıımasının yanı sıra markalaşmasına da büyük katkılar sağlayacağını belirtmiştir (Özkan, 2014).

3 'Türkiye Ulus Markalaması' kavramı bu haliyle literatürde ilk defa kullanıımıştır. Kavram, ulus markalamasının ruhuna uygun olarak Türkiye vatandaşlarının genelini kapsayacak bir ulus markalaması anlayışını tanımlamaktadır. 
Benzer şekilde ekonomi (yatırım ve dışsatım) odakı 'Turquality Projesi', 'Türkiye Markası' ve benzer çalışmaların, Türkiye'nin uluslararası kamuoyu nezdinde saygınlığının artııııması, ulusal imajı konusundaki kafa karışıklıklarının giderilmesi, mevcut önyargıların ortadan kaldırılması ve iç hedef anlamında Türkiye ulusunun ortak bir dünya görüşü ve amaç birliği etrafında bir araya gelmesi için yeterli olmayacağı açıktır. Esas olarak günümüzde ülkelerin dış iletişimlerinin ve yabancı halklarla ilişkilerinin yönetimi olarak tanımlanmaya başlanan kamu diplomasisi anlayışının geliştirilmesi, yapılandırılması büyük önem arz etmektedir. Toplumların birbirini tanıması, anlaması ve önyargıların giderilmesi sağlıklı iletişim ve ilişki kanallarıyla mümkündür.

Türkiye'de bu amacı gerçekleştirmek ve bu çalışmaları yürütecek kurumları koordine etmek için kurulan Kamu Diplomasisi Koordinatörlüğü’nün (KDK) hem kurumsal yapısı hem de kamu diplomasisi anlayışı geliştirilmeli, güçlendirilmeli ve hükümet-sivil ortaklığında işleyecek üst bir mekanizmaya dönüştürülmelidir. Bu hem 'Türkiye Markası' (Türkiye'ye ilişkin yer ve ürün markalamaları) için hem de daha üst sevide Türkiye ulus markalamasının en önemli gereğidir. Kapsamlı stratejiye, koordinasyona intiyaç duyulan, Türkiye'nin kültür, değer, kimlik, imaj konularının ve iletişimlerinin değerlendirilebileceği bir yapı ve işbirliği sistemi Türkiye ulus markalaması ve Türkiye kamu diplomasisi kavramlarının ve uygulamalarının daha doğru zeminlerde tartışıımasını ve değerlendirilmesini mümkün kılacaktır. Bu yapılar ve tasarımlar, Türkiye'nin içerde ve dışarıda yaşadığı birçok problem alanının çözümüne yönelik ortak bir bilinç ve muhayyileye de kapı aralayacaktır.

\section{Sonuc}

Globalleşen dünyada ülkeler ve hükümetler diğer ülkeler ve halklarıyla politik, ekonomik, kültürel ve sosyal ilişkiler kurma ihtiyacı ve isteği içindeler. Bu ilişkiler zaman zaman zorunluluk gibi görünse de ülkelere ve halklarına birçok açıdan fayda sağlamakta. Öyle ki, günümüzde ülkelerin güvenlik, istikrar, gelişmişlik ve saygınlıkları bu ilişkilerin yoğunluğuna ve niteliğine bağlı. Ülkeler arasında gerçekleşen ekonomik ilişkiler ve ticari faaliyetler ile kültürel ve toplumsal ilişkiler günümüz toplumlarının vazgeçilmez konuları. Ve uluslararası siyasal iletişimi tamamlayan alanlar. Birbirine ilişki ağlarıyla sıkı sıkıya bağlanan ülkeler için diğer ülke halkları da kendi halkları kadar önemli. Ülkeler ve hükümetler için global konular ve sorunlar karşısında bu halklarla işbirliği gerekliliği ortaya çıktığı gibi inmaller söz konusu olduğunda da, bu halklara (kamuoyuna) hesap verme zorunluluğu doğmaktadır.

Klasik dış politika ve diplomasi alanını genişleten yer yer onu değiştiren bu süreçlerde, ülkeler ve hükümetler, diğer ülkelerin siyasal aktörleri, bürokratları, medya ve sivil toplum örgütleri,sıradan vatandaşları ile ilişki kurmanın ve onların kalbini ve aklını kazanmanın yollarını aramaktadır. İç ve dış politikalar konusunda bilgilendirme, ülke imajı ve değerleri konusunda sempati yaratma, dış politika ve ekonomi faaliyetleri için uygun ortam yaratma ve destek oluşturma bu faaliyetlerin amaçlarından sadece birkaçı. Yabancı halkların aklını ve kalbini kazanmayı amaçlayan, bireyleri ve grupları anlamaya ve onları etkilemeye dönük yumuşak güç unsurlarına dayanan kamu diplomasisi (Armstrong, 2009: 64) ile yabancı ülke halklarının zihinlerinde olumlu imaj ve algı oluşturmaya çalışan ulus markalaması kavramları aynı evrende benzer amaçlar için benzer stratejiler ve faaliyetler gerçekleştirmektedir (Rawson, 2007: 2015).

Kamu diplomasisi ve ulus markalaması arasındaki ortak özellik, dış politika konularına odaklanan klasik diplomasi yerine değerlere, kültüre, bireysel ve kurumsal ilişkilere, diyalogun ve ilişkinin inşa edilmesine vurgu yapmalarıdır (Bolin ve Stahlberg, 2002: 82). Uluslar arası ilişkiler ve uluslar arası pazarlama iletişimi alanlarından gelen bu iki kavram günümüzde birbirine yaklaşmakta ortak 
konseptler çerçevesinde kuramsal çalışmalara ve pratik uygulamalara olanaklar sağlamaktadır. İki alan arasındaki ilişkiyi ve yarattıkları iletişim ve ilişki olanakları ele alan bu çalışmada, iki kavram arasındaki ilişki iki ana görüş etrafında değerlendirilmiştir. Bunlardan ilki, kamu diplomasisi ve ulus markalaması arasında herhangi bir ilişki ve yakınlık olmadığına yönelik olmuştur. Kamu diplomasisinin, ulus markalamasına göre daha geniş bir alanı kapsadığı savunulmuş, ulus markalamasının genel kitleye, ağırlıklı olarak olumlu imajları tek yönlü sunarken, kamu diplomasisinin ise kitleleri özelleştirerek, onlarla çift yönlü bir diyalog süreci kurmaya çalıştığı ifade edilmiştir. (Szondi, 2008: 16).

İkinci olarak, kamu diplomasisi ve ulus markalaması arasında yakınlık olduğu, benzer amaçlar için benzer araçları kullandıkları, hatta iki kavramın aynı anlama gelecek şekilde birleşme eğiliminde olduğu belirtilmiştir. Bu benzerlikler imaj, sembol üretimi, ilişki inşa etme ve kitle iletişiminin yoğun kullanımı olarak sıralanmıştır (Erzen, 2012: 112). Kamu diplomasisinin, ulus markalamasının bir parçası olduğunu belirten görüşler olduğu gibi ulus markalamasının, kamu diplomasisinin bir parçası olduğunu savunan görüşler de olmuştur. Kamu diplomasisi ve ulus markalamasının neredeyse aynı şey olduğu da ileri sürülmüştür. Iletişim (kamu diplomasisi) ve imaj oluşturma (ulus markalaması) kavramlarının yerine iki kavram birleştirilerek merkezi bir kavram olan ilişki kurma konsepti önerilmiştir (Szondi, 2008: 27). Bazı görüşler ise iki alanı öyle yakınlaştırmıştır ki kamu diplomasisinden ülkelerin marka iletişimi olarak bahsedilmiştir (Mengü ve Yıldırım, 2012: 72).

Literatürdeki görüşler ve değerlendirmeler dikkate alındığında iki kavram arasında birçok konuda benzerlikler ve yakınlıklar bulunmaktadır. Her iki alanda yürütülen çalışmalar doğrudan ülkelerin dış iletişimleri ve imajlarıyla ilişkilidir. Bu iletişimin yönetilmesi, yabancı halklar nezdinde oluşacak imajların ve algıların niteliğini de belirlemektedir. Ülkelerin yürüttükleri markalama çalışmalarını, yer markalaması, şehir markalaması, ülke markalaması ve ulus markalaması olarak somut değerlerden soyut değerlere doğru sıraladığımızda en üst düzeyde yer alan ulus markalaması kimlik, kültür, değer ve imajlarla ilişkili olacağından, kamu diplomasisiyle bağlantıı hale gelmektedir. Çoğu zaman ekonomik ve kalkınma amaçı gerçekleştirilen yer ve ülke markası çalışmaları ulusların diğer toplumlarla toplam iletişimlerini yönetmeleri ve imajlarını oluşturmaları konularında yetersiz kalmaktadır.

Yer ve ülke markalaması çoğu zaman turizm, dışsatım, ürün ve hizmet markaları ile ilgili ekonomik konularla sınırlandırılmaktadır. Ulus markalaması, ulus imajı, değer ve kültür politikalarının iletişimi, sembol üretimi, ilişki inşa etme gibi ilişki kurma konseptine dayandığından, benzer konular ve amaçlarla ilişkili olan kamu diplomasisi perspektifinden değerlendirilmeye olanaklar sunmaktadır. Kamu diplomasisi anlayışı, alanları ve faaliyetleri ulus markalamasına uygun bütüncül bir ilişki kurma konsepti ve uygulama ortamları sağlarken, ulus markalaması da kimlik, değer, imaj gibi konuların daha stratejik ve derinlemesine incelenmesini, modern markalama ve pazarlama anlayışının tekniklerinden destek alarak iç ve dış kamulara sunulmasını sağlamaktadır.

İki alan arasındaki ilişki özelinde kamu diplomasisi perspektifinin, Türkiye ulus markalamasına katkısı değerlendirildiğinde, yapılacak olan ulus markalaması çalışmalarının sürekliliği ve bütünlüğü için Türkiye kamu diplomasisi anlayışının ve kurumsal kapasitesinin geliştirilmesi gerekmektedir. Sivil toplum ve kurumlarının sadece faaliyet süreçlerinde değil yönetim süreçlerinde de yer alabileceği, devlet/hükümet ve sivil toplum ortaklığında kurgulanan güçlü bir üst yapı, Türkiye'nin tüm farklııklarını, kültürel zenginliklerini ve politikalarını bütünlüklü bir şekilde yabancı halklara yansıtabilecektir. Türk dış politikasının ve temsilcilerinin tek başlarına günümüzdeki çoklu iletişim ve ilişki alanlarını yönetmeleri ve yabancı halklarla ilişki kurmaları mümkün değildir. Türkiye kamu 
diplomasisi alanlarında faaliyet gösteren devlet/hükümet ve sivil toplum kurumları arasında bir koordinasyon ve strateji birliği olmadığında gerçekleştirilecek faaliyetler doğrudan Türkiye'nin dış imajına ve saygınlığına katkı sağlamayacaktır.

Bunun en açık örneği, Türkiye'nin dünyada en fazla insani yardım yapan üçüncü ülke olmasına rağmen (KDK, 2013), bu özelliğinin uluslararası kamuoyunda yeterince bilinmemesi ve bir imaj ve saygınlık siyasetine dönüştürememiş olmasıdır. Aynı şekilde daha önce değerlendirilmiş olan ekonomik temelli 'ülke markası' çalışmalarının, daha üst düzeyde ulus markalaması çalışmalarına bir katkısının olmamış, ekonomik girişimler olarak kalmıştır. Kamu diplomasisi alanında gerçekleştirilecek olan devlet/hükümet ve sivil toplum ortaklığı çalışmalar ve kurumsallaşmalar, Türkiye'nin ortak karar alma bilincini ve birlikte temsil duygusunu da arttıracağından, Türkiye demokrasisini ve farklılıkların birlikte yaşama duygusunu geliştirecektir. Yabancı halklar nezdinde ya da uluslararası kamuoyunun zihninde birçok Türkiye imajının oluşmasında bu koordinasyonsuzluğun ve kimlik ve imaj konusundaki kafa karışıklıklarının büyük etkisi bulunmaktadır. Bu yüzden Türkiye kamu diplomasisi ve ulus markalamasının gündemlerinden biri de bu iç kamuoyuna yönelik ortak kimlik ve bilinç geliştirmeye yönelik çalışmalar olmalıdır.

Türkiye ve Türk dış politikasının son yıllarda sağladığı gelişme ve genişleme Türkiye kamu diplomasisi içinde yeni alanlar ve iletişim olanakları sunmaktadır. Bu alanlarda yabancı kamularla kurulacak ilişkiler doğrudan, mevcut olumsuz algıların ve imajların ortadan kaldırılmasına olanak sağlayacak, yeni imajların, değerlerin ve politikalarında sunulmasına imkan tanıyacaktır. Bu iletişim ve ilişki gerekliliği salt geleneksel diplomasi yöntemleri, tanıtım ve bilgilendirme çalışmaları, kısa dönemli ekonomik ülke markası projeleri ile geçiştirilmemelidir. Ekonomik temelli turizm, dış yatırım ve dışsatım çalışmaları ve tanıtımları Türkiye'nin uluslararası imajına, kısmen de itibarına kısa dönemli katkılar sağlasa da Türkiye ulus markalaması ve yönetimi anlamına gelmeyecektir.

Türkiye kamu diplomasisi anlayışı ve kurumsal yapısı, Türkiye'nin dış iletişimini ve itibarını yönetecek ve kamu diplomasisine katkı sunan diğer kurumları koordine edebilecek bir yeterliliğe kavuşturulduğu takdirde hükümet ve sivil toplum ortaklığında bir ulus markalaması konsepti ve felsefesi geliştirilebilecek ve uygulanabilecektir. Kamu diplomasisi anlayışı ve sistemi geliştirilmeden ulus markalaması için uygun ve doğru yöntemler ortaya çıkamayacaktır. Bu dönüşümün sağlanmasında devlet ve hükümet kurumları öncülük ve koordinatörlük görevi üstlenebilirler ancak bu alanların ve kurumların doğrudan hükümetler ve bağlı kurumları tarafından yönetilmesi yeni kamu diplomasisi anlayışına uygun değildir.

Bununla birlikte, Anholt, devletleri, ülkelerinin imajının ve itibarının en önemli sorumlulukları olduğunu fark etmeleri ve bu konuyu çok dikkate almaları gerektiği konusunda uyarmış, eğer buna önem vermezlerse, o zaman, daha güçlü bir devletin, onlar için ülkelerinin 'marka yapısı'nı oluşturacağını belirtmiştir. Devletlerin bu sürece tüm kaynaklarını, daha da önemlisi devletin, özel sektörün, kültür, eğitim, din gibi alanların en değerli ve etkili kişilerini ve temsilcilerini seferber etmeleri gerektiğini vurgulamış, ülkenin markalaşma stratejisiyle turizm tanıtımını ya da yatırım tanıtımını birbirine karışırmamaları gerektiğini ifade etmiştir (Tuncer, 2005).'Türkiye Kamu Diplomasisi' ve 'Türkiye Ulus Markalaması' süreçleri birbirine entegre edilerek yönetildiği takdirde yukarıda bahsedilen 'marka yapısı' ortaya çıkacak ve bu yapının unsurları, değerleri ve imajları Türkiye’nin iç ve dış kamuoyuna sunulacaktır. 


\section{Kaynakça}

Amstrong, M. C.(2009). "Operationalizing Public Diplomacy," Handbook of Public Diplomacy. Nancy Snow, Philip M. Taylor (der.) içinde. New York. Routledge.

Brandage (2012). "Wally Olins “Tüm Dünyanın Gözü Türkiye’nin Üzerinde”. http://thebrandage.com/wally-olinstum-dunyanin-gozu-turkiyenin-uzerinde/. 22.05.2015.

Bolin, G. and Stahlberg, P. (2002). "Between Community and Commodity: Nationalism and Nation Branding." Communicating the Nation. Anna Roosvall and Inka Salovaara (der.) içinde. Moring. Sweden: Nordicom.

Cull, N. (2009). "Public Diplomacy Before Gullion." Handbook of Public Diplomacy. Nancy Snow, Philip M.Taylor, (der.) içinde. Routledge.

Demir, V. (2012). Kamu Diplomasisi ve Yumuşak Güç. İstanbul: Beta.

Erzen, M. Ü. (2012). Kamu Diplomasisi. İstanbul: Derin.

Gudjonsson, H. (2005). "Nation Branding". Place Branding. 1(3): 283-298.

Ham, P. V. (2007). "Power, Public Diplomacy and the Pax Americana." The New Public Diplomacy Soft Power inInternational Relations.Jan Melissen (der.) içinde. Second Edition. New York: Palgrave Macmillan.

İnan, E. (2012). "Kamu Diplomasisi ve Halkla ilişkiler Ekseni.” Kamu Diplomasisi. Abdullah Özkan, Tuğçe Ersoy Öztürk (der.) içinde. İstanbul: Tasam.

KDK (2013).“Uluslararası yardımlarda 'en cömert ülke' unvanını taşıyan Türkiye'nin yardım seferberliği sürüyor”. http://kdk.gov.tr/haber/turkiyenin-dis-yardimlari-2013/494. 26.05.2015.

"KDK Genelgesi." (2010). http://kdk.gov.tr/faaliyetler/kdk-genelgesi/5. 29.04.2015.

“KDK Vizyon \& Misyon" (2015). http://kdk.gov.tr/faaliyetler/vizyon-misyon/8. 23.05.2015.

Köksoy, E. (2013) Halkla İlişkiler Bağlamında Kamu Diplomasisi Yönetimi. Yayınlanmamış Doktora Tezi. İstanbul. İ.Ü.SBE.

Krause, P. and Evera, S. V. (2009). "Public Diplomacy: Ideas for the War of Ideas" Discussion Paper 09-10. Belfer Center for Science and International Affairs. Harvard Kennedy School.

Leonard, M. and Alakeson, V. (2000). Going public: Diplomacy for the Information Society. London: The Foreign Policy Centre.

Mengü, S. Ç. ve Yıldıım, G. (2012). "Halkla İlişkilerin Kamu Diplomasisinde Etkin Kullanımı". Kamu Diplomasisi. Abdullah Özkan, Tuğçe Ersoy Öztürk (der.) içinde. İstanbul: Tasam.

Moon, M. ve Millison D. (2003). Ateşten Markalar-Internet Çağında Marka Sadakati Yaratmanın Yolları. MediaCat.

Potter, E. (2009). Branding Canada.Canada: McGill-Quenn's University Press. 
Rawson, E. A. (2007). "Perceptions of the United States of America: Exploring the Political Brand of a Nation." Place Branding and Public Diplomacy. 3(3): 213-221.

Signitzer, B. ve Coombs, T. (1992). "Public Relations and Public Diplomacy: Conceptual Convergences." Public Relations Review. 18 (1): 137-147.

Snow, N. (2009). "Rethinking Public Diplomacy". Handbook of Public Diplomacy. Nancy Snow and Philip M. Taylor (der.) içinde. Routledge.

Szondi, G. (2009). "Central and Eastern European Public Diplomacy”. Handbook of Public Diplomacy. Nancy Snow, Philip M.Taylor (der) içinde. Routledge.

Szondi, G. (2008). "Public Diplomacy and Nation Branding: Conceptual Similarities and Diffirences”. Netherlands Institute of International Relations Clingendael. October:1-42.

Tuch, H. N. (1990). Communicating ith the World: U.S. Public Diplomacy Overseas. St. Martin's Press Inc.

Zaharna,R.S. (2009). "Mapping out a Spectrum of Public Diplomacy Initiatives-Information and Relational Communication Frameworks." Handbook of Public Diplomacy. Nancy Snow ve Philip M. Taylor (der.) içinde. Routledge.

Zengin, Gürkan (2010) Hoca, Türk Dış Politikasında Davutoğlu Etkisi. İstanbul, 2010: İnkilap.

Brandage (2012). “Wally Olins “Tüm Dünyanın Gözü Türkiye’nin Üzerinde”. http://thebrandage.com/wally-olinstum-dunyanin-gozu-turkiyenin-uzerinde/. 22.05.2015.

Fan, Y. (2010). "Branding The Nation: Towards A Better Understanding" http://www.academia.edu/5185202/ Branding_the_nation_towards_a_better_understanding. 29.04.2015.

Genelge (2015). "Türkiye Markası Logosu ve Sloganı". http://www.resmigazete.gov.tr/ eskiler/2015/04/20150411-14.htm. 22.05.2015.

KDK (2013).“Uluslararası yardımlarda 'en cömert ülke' unvanını taşıyan Türkiye'nin yardım seferberliği sürüyor”. http://kdk.gov.tr/haber/turkiyenin-dis-yardimlari-2013/494. 26.05.2015.

“KDK Genelgesi." (2010). http://kdk.gov.tr/faaliyetler/kdk-genelgesi/5. 29.04.2015.

“KDK Vizyon \& Misyon” (2015). http://kdk.gov.tr/faaliyetler/vizyon-misyon/8. 23.05.2015.

Özkan, A. (2014). "Ülke Markası” İnşasında Kamu Diplomasisinin Stratejik Rolü”. http://www.kamudiplomasisi. org/makaleler/makaleler/138-uelke-markas-nasnda-kamu-diplomasisinin-stratejik-rolue. 29.04.2015.

"Public Diplomacy and Nation Branding" (2012). https://publicandculturaldiplomacy3.wordpress. com/2012/04/21/public-diplomacy-and-nation-branding-7/. 21.04.2015.

Sancar, G.A. (2015). “Kamu Diplomasisinde ‘llişki İnşa Etme’ Söylemi”. http://kamudiplomasisi.org/demo/ images/stories/aslisancar.pdf. 26.05.2015. 
TiM (2014). “TiM ve Ekonomi Bakanlığı, Türkiye Markası'nı kamuoyuyla tanıştırdı”. http://www.tim.org.tr/tr/timgundem-tim-ve-ekonomi-bakanligi-turkiye-markasini-kamuoyuyla-tanistirdi.html. 22.05.2015.

Tuncer, A. S. (2005). “Marka adı Törökország!”. http://selimtuncer.blogspot.com.tr/search?q=ulus+markas\%C 4\%B1.22.05.2015.

Turquality (2015). "Turquality Hakkında”.http://turqquality.com/. 23.05.215.

"Public Diplomacy and Nation Branding" (2012). https://publicandculturaldiplomacy3.wordpress. com/2012/04/21/public-diplomacy-and-nation-branding-7/. 21.04.2015.

Sancar, G.A. (2015). “Kamu Diplomasisinde ‘'lişsi İnşa Etme’ Söylemi”. http://kamudiplomasisi.org/demo/ images/stories/aslisancar.pdf. 26.05.2015.

TiM (2014). "TiM ve Ekonomi Bakanlığı, Türkiye Markası'nı kamuoyuyla tanıştırdı”. http://www.tim.org.tr/tr/timgundem-tim-ve-ekonomi-bakanligi-turkiye-markasini-kamuoyuyla-tanistirdi.html. 22.05.2015.

Tuncer, A. S. (2005). "Marka adı Törökország!". http://selimtuncer.blogspot.com.tr/search?q=ulus+markas\%C 4\%B1.22.05.2015.

Turquality (2015). "Turquality Hakkında”.http://turqquality.com/. 23.05.215. 